\title{
REVIEW
}

\section{Review of the efficacy and safety of transanal irrigation for neurogenic bowel dysfunction}

\author{
A Emmanuel \\ Department of Gastroenterology and Nutrition, University College Hospital, London, UK
}

\begin{abstract}
Study design: Neurogenic bowel dysfunction (NBD) is a common occurrence after spinal cord injury $(\mathrm{SCl})$ and in patients with spina bifida or multiple sclerosis. The impact of NBD on well-being is considerable, affecting both physical and psychological aspects of quality of life. Transanal irrigation (TAl) of the colon promotes the evacuation of faeces by introducing water into the colon and rectum through a catheter inserted into the anus. Regular and controlled evacuation in this manner aims at preventing both constipation and faecal soiling.

Objectives: The aim of this study was to review current evidence for the efficacy and safety of TAI in patients with NBD.

Materials and methods: A literature search was conducted in PubMed. All identified papers were assessed for relevance based on the title and abstract; this yielded 23 studies that were considered to be of direct relevance to the topic of the review.

Results: A multicentre, randomized, controlled trial has supported observational reports in demonstrating that TAl offers significant benefits over conservative bowel management in patients with $\mathrm{SCl}$, in terms of managing constipation and faecal incontinence, reducing NBD symptoms and improving quality of life. Among other populations with NBD, TAl shows the greatest promise in children with spina bifida; however, further investigation is required. The overall safety profile of TAl is good, with few, and rare, adverse effects.

Conclusions: Building on the positive data reported for patients with $\mathrm{SCl}$, continued evaluation in the clinical trial setting is required to further define the utility of TAl in other populations with NBD.

Spinal Cord (2010) 48, 664-673; doi:10.1038/sc.2010.5; published online 9 February 2010
\end{abstract}

Keywords: transanal irrigation; neurogenic bowel; spinal cord injury; bowel management; faecal incontinence; constipation

\section{Introduction}

Neurogenic bowel dysfunction (NBD) is a common occurrence after spinal cord injury (SCI), and in patients with spina bifida, multiple sclerosis and other neurological diseases. In patients with SCI, approximately half have moderate-to-severe symptoms associated with $\mathrm{NBD},{ }^{1}$ with $42 \%$ experiencing constipation ${ }^{2}$ and $77 \%$ faecal incontinence. $^{3}$ Approximately $68 \%$ of patients with multiple sclerosis develop bowel symptoms ${ }^{4}$ and $37 \%$ of patients with Parkinson's disease have constipation. ${ }^{5}$ Among children with spina bifida, constipation is very common and one-third are faecally incontinent. ${ }^{6,7}$

Neurological disorder or damage causes bowel dysfunction by disrupting peristalsis (underactive propulsive or overactive segmental), or by precipitating rectal distension or

Correspondence: Dr A Emmanuel, GI Physiology Unit, University College Hospital, 235 Euston Road, London NW1 2BU, UK.

E-mail: a.emmanuel@ucl.ac.uk

Received 26 October 2009; revised 17 December 2009; accepted 27 December 2009; published online 9 February 2010 colonic slowing. The extent of the symptoms of NBD (such as constipation, trouble with defaecation, faecal incontinence) is determined by the underlying pathology. The pathophysiology is related to the extent of injury and is the most important factor in determining bowel symptoms in both SCI and multiple sclerosis. However, whereas lesions are usually sharply defined and unchanging in patients with chronic SCI, lesions typically occur at multiple levels within the central nervous system and tend to vary with time in patients with multiple sclerosis. As sympathetic (inhibitory) innervation to the gut originates from the ninth thoracic to the second lumbar (T9-L2) segments of the spinal cord, clinical classification of SCI describes lesions as: (1) supraconal (above the conus medullaris, where inhibitory input is lost), (2) within the conus or (3) located in the cauda equina (where excitatory sacral parasympathetic supply is lost). In supraconal SCI, an 'upper motor neurone'-type injury of the bowel results, delaying gut transit, ${ }^{8}$ as well as hypertonia and hyperreflexia of the hindgut. ${ }^{9}$ Rectal hypertonia results in reduced rectal compliance and predisposes to reflex 
defaecation and incontinence. In cauda equina lesions, the efferent limb of the reflex arc to the hindgut is interrupted, resulting in a 'lower motor neurone'-type bowel dysfunction with hypotonia and hyporeflexia. ${ }^{10}$ Complete SCI has been shown to result in the most severe degree of bowel dysfunction. $^{11}$

The impact of NBD on an individual can be considerable, affecting self-esteem, personal relationships and social life. ${ }^{3,12}$ The severity of NBD correlates inversely with quality of life ${ }^{1}$ and, in patients with SCI, the impact of NBD has been rated as significantly greater than other aspects of the condition. ${ }^{13}$

Despite the impact of unmanaged NBD on well-being, there is a tendency for bowel management to be considered a low health-care priority. Embarrassment and taboos regarding bowels and incontinence can create a further barrier to effective treatment. In addition, there is a common misconception that no effective treatment options are available. Indeed, a limited number of options are available for managing the symptoms of NBD.

The so-called conservative management strategies are widely used, comprising diet modification, laxatives, rectal suppositories, digital stimulation and digital evacuation. By emptying the bowel regularly, manual evacuation reduces the risk of unplanned evacuations; ${ }^{14}$ however, it can take several hours to complete and must be repeated every 2-3 days. The goals of bowel care for people with NBD should include promoting dignity and autonomy; these goals are as essential as reducing urinary tract infection and skin damage. Therefore, the ideal bowel management regimen should be self-conducted to promote self-esteem, privacy and independence, as well as to minimize carer-associated costs.

Transanal irrigation (TAI) of the colon is designed to assist the evacuation of faeces from the bowel by introducing water into the colon and rectum through the anus. The water is introduced using a specialized catheter and subsequently evacuated, when the catheter is removed, together with the contents of the rectum, sigmoid and, possibly, the descending colon. By regularly emptying the bowel in this manner, TAI is intended to help re-establish controlled bowel function and enable the user to choose the time and place of evacuation. In patients with faecal incontinence, efficient emptying of the colon and rectum means that new faeces do not reach the rectum for $\sim 2$ days, ${ }^{15}$ thereby preventing leakage between irrigations. In patients with constipation, regular evacuation of the rectosigmoid region can promote transport through the entire colon and therefore prevent blockages.

Two commercially available TAI systems have been studied-Peristeen (Coloplast A/S, Humlebaek, Denmark; Figure 1) and the Enema Continence Catheter (Cardiomed Supplies, ON, Canada). Data are also available on other equipments, such as stoma irrigation systems with a coneshaped tip. The fine-tuning of actual techniques for irrigation varies between centres, with no standard protocols having been subjected to trial. Rather, these techniques are adapted according to individual patients.

There has been no previous comprehensive literature review of TAI in patients with NBD. Therefore, the aim of

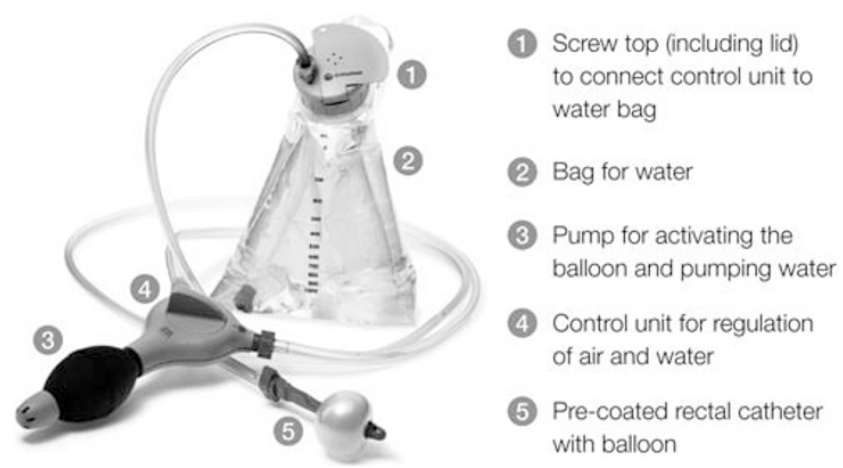

Figure 1 The Peristeen (Coloplast A/S, Humlebaek, Denmark) transanal irrigation system.

this research was to review and consolidate evidence for the efficacy and safety of TAI in patients with chronic NBD.

A literature search was conducted in PubMed using the following search terms: 'transanal irrigation'; 'retrograde continence catheter'; 'retrograde colonic irrigation'; 'neurogenic bowel dysfunction'; 'transrectal irrigation'; 'bowel dysfunction' and 'cauda equina' or 'spinal cord injury' or 'spina bifida' or 'multiple sclerosis'; 'bowel management' and 'cauda equina' or 'spinal cord injury' or 'spina bifida' or 'multiple sclerosis'; 'conservative bowel management' and 'cauda equina' or 'spinal cord injury' or 'spina bifida' or 'multiple sclerosis'; 'enema continence catheter'; 'Shandling catheter'; 'water enema'; 'colonic irrigation'; and 'colonic enema'. A total of 430 papers were identified and assessed for relevance to the article based on the title and abstract. This yielded 23 studies that were considered to be of direct relevance to the subject of the review article; the remaining studies were not specifically related to the topic of TAI for NBD or did not report relevant primary data. All studies on TAI in patients with NBD were included in the short list (Table 1), regardless of their size or design. With the exception of one large, randomized controlled trial (RCT), most studies were retrospective or observational in nature.

\section{Efficacy of TAl in patients with $\mathrm{SCl}$ or cauda equina}

An initial open study of an Enema Continence Catheter in 15 patients with NBD (3 with supraconal SCI and 12 with conal or cauda equina injury) showed some promise at the time of follow-up of up to 51 months. ${ }^{16}$ Symptom improvement was observed in 1 of 3 patients with supraconal SCI and in 7 of 12 patients with conal SCI.

The efficacy of TAI in patients with SCI was subsequently investigated more definitively in a multicentre, RCT of TAI with Peristeen compared with conservative bowel management. ${ }^{17}$ This prospective, European trial is currently the largest of its type to address bowel management in patients with SCI. In this trial, 87 adults with SCI and NBD were randomized to either 10 weeks of TAI with lukewarm tap water $(n=42)$ or 10 weeks of conservative bowel management comprising best supportive management without irrigation $(n=45) .{ }^{17} \mathrm{SCI}$ was attributed to various aetiologies, 
Table 1 Efficacy of transanal irrigation in patients with neurogenic bowel dysfunction

\begin{tabular}{|c|c|c|c|c|c|}
\hline Patients & Study design & System/equipment & Main findings & $\begin{array}{l}\text { Strengths (+)/ } \\
\text { limitations (-) }\end{array}$ & Reference \\
\hline \multicolumn{6}{|c|}{$\mathrm{SCI}$ (including mixed populations with a high proportion of SCI patients) } \\
\hline $\begin{array}{l}\text { SCl, } n=87 \\
\text { (including } \\
\text { spina bifida, } \\
n=2 \text { ) }\end{array}$ & $\begin{array}{l}\mathrm{RCT}, 10 \text { weeks } \\
N=42 \text { allocated } \\
\text { to Peristeen }\end{array}$ & $\begin{array}{l}\text { TAl with } \\
\text { Peristeen versus } \\
\text { conservative } \\
\text { management }\end{array}$ & $\begin{array}{l}\text { - Reduced symptoms of constipation } \\
\text { (Cleveland Clinic constipation scoring system) } \\
\text { - Reduced symptoms of faecal incontinence } \\
\text { (St Mark's faecal incontinence grading system) } \\
\text { - Reduced symptoms of NBD (NBD score) } \\
\text { - Improved QoL (Modified American Society } \\
\text { of Colon and Rectal Surgeons fecal } \\
\text { incontinence score, numeric scale) } \\
\text { - Reduced time spent on bowel management } \\
\text { - Improved intestinal functionality } \\
\text { - (numeric box scale) } \\
\text { - Reduced UTls }\end{array}$ & $\begin{array}{l}\text { + Prospective } \\
\text { + RCT (CONSORT) } \\
\text { + Multicentre } \\
\text { + Standard scoring } \\
\text { systems/scales }\end{array}$ & $\begin{array}{l}\text { Christensen } \\
\text { et al. }{ }^{17}\end{array}$ \\
\hline $\begin{array}{l}\mathrm{SCl}, n=62 \\
\text { (including }^{\text {spina bifida, }} \\
n=2 ; 42 \text { from } \\
\mathrm{RCT})^{\mathrm{a}}\end{array}$ & $\begin{array}{l}\text { Prospective, } \\
\text { before-after study, } \\
10 \text { weeks } \\
\text { Extension to RCT; } \\
\text { patients in conservative } \\
\text { arm offered cross-over } \\
\text { to Peristeen }\end{array}$ & Peristeen & $\begin{array}{l}\text { - Confirmed findings from RCT } \\
\text { - No predictors of successful outcome } \\
\text { identified; supports trial of TAI in all suitable } \\
\text { patients }\end{array}$ & $\begin{array}{l}+ \text { Prospective } \\
- \text { Non-comparative }\end{array}$ & $\begin{array}{l}\text { Christensen } \\
\text { et al. }\end{array}$ \\
\hline $\begin{array}{l}\mathrm{SCl}, n=33 \\
\text { (including } \\
\text { spina bifida, } \\
n=12 ; \mathrm{MS} \\
n=2 \text { ) }\end{array}$ & $\begin{array}{l}\text { Prospective, before-after } \\
\text { study, } 3 \text { weeks }\end{array}$ & Peristeen & $\begin{array}{l}\text { - Reduced symptoms of NBD (NBD score) } \\
\text { - Improved QoL } \\
\text { - Increased degree of satisfaction } \\
\text { - Reduced time spent on bowel } \\
\text { management } \\
\text { - Improved intestinal functionality } \\
\text { - No adverse events reported }\end{array}$ & $\begin{array}{l}\text { + Prospective } \\
\text { - Non-comparative } \\
\text { - Short duration }\end{array}$ & $\begin{array}{l}\text { Del Popolo } \\
\text { et al. }{ }^{19}\end{array}$ \\
\hline $\begin{array}{l}\text { Mixed NBD, } \\
n=21 \\
\text { (including SCl, } \\
n=15, \text { spina } \\
\text { bifida, } n=5 \text { ) }\end{array}$ & $\begin{array}{l}\text { Questionnaire follow-up } \\
\text { and chart review, } \\
\text { non-randomized study, } \\
\text { mean follow-up } \\
16 \text { months }\end{array}$ & $\begin{array}{l}\text { Enema } \\
\text { Continence } \\
\text { Catheter }\end{array}$ & $\begin{array}{l}\text { - Success in } 57 \% \text { of patients } \\
\text { - Overall, } 53 \% \text { still using irrigation } \\
\text { at follow-up } \\
\text { - Improved QoL }\end{array}$ & $\begin{array}{l}\text { + No loss to follow-up } \\
\text { - End points not } \\
\text { clearly pre-defined } \\
\text { - Small number of } \\
\text { patients }\end{array}$ & $\begin{array}{l}\text { Christensen } \\
\text { et al. }\end{array}$ \\
\hline $\begin{array}{l}\text { Mixed NBD, } \\
n=211 \\
\text { (including SCl, } \\
n=173 \text { (spina } \\
\text { bifida, } n=32 \text { ), } \\
\text { MS, } n=25 \text { ) }\end{array}$ & $\begin{array}{l}\text { Questionnaire follow-up } \\
\text { and chart review, mean } \\
\text { follow-up } 19 \text { months }\end{array}$ & $\begin{array}{l}\text { Rectal balloon } \\
\text { catheter, } \\
\text { cone-shaped } \\
\text { colostomy tip } \\
\text { or other systems }\end{array}$ & $\begin{array}{l}\text { - Successful outcome in } 46 \% \text { of patients } \\
\text { - Overall, } 35 \% \text { success rate at } 3 \text { years } \\
\text { - Positive influence on } \mathrm{QoL} \\
\text { - Minor side effects in } 48 \% \text { of patients } \\
\text { - One non-lethal bowel perforation in } \\
50000 \text { irrigations }(0.002 \%)\end{array}$ & $\begin{array}{l}\text { + No loss to follow-up } \\
+ \text { Large number of } \\
\text { patients } \\
+ \text { Long follow-up } \\
\text { - Non-comparative }\end{array}$ & $\begin{array}{l}\text { Faaborg } \\
\text { et al. }\end{array}$ \\
\hline $\begin{array}{l}\text { Mixed patients } \\
\text { with } \\
\text { constipation or } \\
\text { incontinence, } \\
n=348 \\
\text { (including } \mathrm{SCl} \text {, } \\
n=68 \text {, spina } \\
\text { bifida, } n=18, \\
\text { MS, } n=10 \text { ) }\end{array}$ & $\begin{array}{l}\text { Questionnaire follow-up } \\
\text { and review of hospital } \\
\text { records, mean } \\
\text { follow-up } 21 \text { months }\end{array}$ & $\begin{array}{l}\text { Enema continence } \\
\text { catheter, Peristeen } \\
\text { or a cone-shaped } \\
\text { colostomy tip } \\
\text { (Alterna, Coloplast } \\
\text { A/S, Humlebaek, } \\
\text { Denmark) }\end{array}$ & $\begin{array}{l}\text { - Successful outcome in } 47 \% \text { of patients } \\
\text { - Two non-fatal bowel perforations in } \\
\sim 110000 \text { irrigations }\end{array}$ & $\begin{array}{l}+ \text { Large number of } \\
\text { patients } \\
- \text { Non-comparative }\end{array}$ & $\begin{array}{l}\text { Christensen } \\
\text { et al. }{ }^{21}\end{array}$ \\
\hline \multicolumn{6}{|c|}{ Spina bifida (also see above) } \\
\hline $\begin{array}{l}\text { Spina bifida, } \\
n=40 \text { youths }\end{array}$ & $\begin{array}{l}\text { Prospective study, } \\
\text { mean follow-up } \\
12 \text { months }\end{array}$ & Peristeen & $\begin{array}{l}\text { - Reduced symptoms of bowel dysfunction } \\
\text { - Reduced requirement for assistance } \\
\text { from carer } \\
\text { - Improved opinion of intestinal functionality } \\
\text { - High level of satisfaction } \\
\text { - No adverse events reported }\end{array}$ & $\begin{array}{l}\text { + Prospective } \\
+ \text { Defined end points } \\
+ \text { Intermediate } \\
\text { follow-up } \\
- \text { Non-comparative }\end{array}$ & $\begin{array}{l}\text { López } \\
\text { Pereira } \\
\text { et al. }\end{array}$ \\
\hline $\begin{array}{l}\text { Spina bifida, } \\
n=31 \text { children } \\
\text { (including } \mathrm{SCl} \\
n=1 \text { ) }\end{array}$ & $\begin{array}{l}\text { Prospective, } \\
\text { before-after study, } \\
30 \text { months }\end{array}$ & $\begin{array}{l}\text { Enema } \\
\text { Continence } \\
\text { Catheter }\end{array}$ & $\begin{array}{l}\text { - Increased proportion of continent stools } \\
\text { - Decreased proportion of constipated stools } \\
\text { - Increased satisfaction with bowel } \\
\text { programme } \\
\text { - No adverse events reported }\end{array}$ & $\begin{array}{l}+ \text { Prospective } \\
- \text { Non-comparative }\end{array}$ & $\begin{array}{l}\text { Liptak and } \\
\text { Revell }^{27}\end{array}$ \\
\hline
\end{tabular}


Table 1 Continued

\begin{tabular}{|c|c|c|c|c|c|}
\hline Patients & Study design & System/equipment & Main findings & $\begin{array}{l}\text { Strengths }(+) / \\
\text { limitations (-) }\end{array}$ & Reference \\
\hline $\begin{array}{l}\text { Spina bifida, } \\
n=112 \text { children }\end{array}$ & Descriptive & $\begin{array}{l}\text { Enema } \\
\text { Continence } \\
\text { Catheter }\end{array}$ & - Achieved continence rate of $100 \%$ & $\begin{array}{l}\text { + Large number of } \\
\text { patients } \\
\text { - Non-comparative } \\
\text { - End point not } \\
\text { defined }\end{array}$ & $\begin{array}{l}\text { Shandling } \\
\text { and } \\
\text { Gilmour }^{24}\end{array}$ \\
\hline $\begin{array}{l}\text { Spina bifida, } \\
n=10 \text { children }\end{array}$ & $\begin{array}{l}\text { Descriptive, } \\
\text { follow-up } \\
4-30 \text { months }\end{array}$ & $\begin{array}{l}\text { Enema } \\
\text { Continence } \\
\text { Catheter }\end{array}$ & - Successful in 7 of 10 patients & $\begin{array}{l}\text { - End point not } \\
\text { defined } \\
\text { - Non-comparative } \\
\text { - Small number of } \\
\text { patients }\end{array}$ & $\begin{array}{l}\text { Walker } \\
\text { and } \\
\text { Webster }^{25}\end{array}$ \\
\hline $\begin{array}{l}\text { Spina bifida, } \\
n=33 \text { children }\end{array}$ & $\begin{array}{l}\text { Descriptive, } \\
\text { follow-up; up to } \\
35 \text { months }\end{array}$ & $\begin{array}{l}\text { Enema } \\
\text { Continence } \\
\text { Catheter }\end{array}$ & - Continence achieved in 32 of 33 patients & $\begin{array}{l}\text { - End point not } \\
\text { defined } \\
\text { - Non-comparative } \\
\text { - Small number of } \\
\text { patients }\end{array}$ & Eire et $a .^{26}$ \\
\hline $\begin{array}{l}\text { Spina bifida, } \\
n=24 \text { children } \\
\text { (subgroup of } \\
\text { larger study) }\end{array}$ & Descriptive & Irrigation cone & $\begin{array}{l}\text { - (Pseudo) continence achieved in } 21 \text { of } \\
24 \text { patients }\end{array}$ & $\begin{array}{l}\text { - Non-comparative } \\
\text { - Small number of } \\
\text { patients }\end{array}$ & $\begin{array}{l}\text { Vande Velde } \\
\text { et } a .^{28}\end{array}$ \\
\hline $\begin{array}{l}\text { Spina bifida, } \\
n=6 \text { adults }\end{array}$ & Descriptive & $\begin{array}{l}\text { Retrograde } \\
\text { colonic washout }\end{array}$ & $\begin{array}{l}\text { - } 3 \text { Patients were continent but only } 1 \\
\text { reported adherence to therapy }\end{array}$ & $\begin{array}{l}\text { - Non-comparative } \\
\text { - No follow-up } \\
\text { - Small number of } \\
\text { patients }\end{array}$ & Wright $^{31}$ \\
\hline $\begin{array}{l}\text { Spina bifida, } \\
n=41 \text { children }\end{array}$ & $\begin{array}{l}\text { Questionnaire follow-up } \\
\text { and chart review, mean } \\
\text { follow-up } 33 \text { months }\end{array}$ & $\begin{array}{l}\text { Cone-tipped } \\
\text { catheter }\end{array}$ & $\begin{array}{l}\text { - Complete faecal continence achieved } \\
\text { in } 66 \% \text { of patients } \\
\text { - Constipation in } 39 \% \text { of patients; no } \\
\text { cases of faecal retention or impaction } \\
\text { - Satisfaction rated high by } 63 \% \text { and } \\
\text { good by } 37 \% \text { of patients } \\
\text { - In all, } 5 / 41 \text { Patients dependent on } \\
\text { others for TAl procedure }\end{array}$ & $\begin{array}{l}\text { + Long follow-up } \\
\text { - Non-comparative } \\
\text { - End points not pre- } \\
\text { defined }\end{array}$ & $\begin{array}{l}\text { Schöller- } \\
\text { Gyüre } \\
\text { et al. }\end{array}$ \\
\hline $\begin{array}{l}\text { Spina bifida, } \\
n=40 \text { children }\end{array}$ & $\begin{array}{l}\text { Questionnaire follow-up } \\
\text { study, median follow-up } \\
1.5 \text { years }\end{array}$ & $\begin{array}{l}\text { Stoma Cone } \\
\text { Irrigation Set or } \\
\text { Colotip }\end{array}$ & $\begin{array}{l}\text { - Procedure worked satisfactorily in } 85 \% \\
\text { - All patients were constipation-free } \\
\text { - In all, } 35 / 40 \text { were faecally continent }\end{array}$ & $\begin{array}{l}\text { + Defined end points } \\
\text { - Non-comparative }\end{array}$ & $\begin{array}{l}\text { Mattsson } \\
\text { and Gladh }\end{array}$ \\
\hline \multicolumn{6}{|c|}{ Other/mixed populations } \\
\hline $\begin{array}{l}\text { Mixed, } n=169 \\
\text { (including } \\
\text { anterior } \\
\text { resection } \\
\text { or pouch } \\
\text { surgery, } \\
n=29 \text { ) }\end{array}$ & $\begin{array}{l}\text { Questionnaire follow-up } \\
\text { study of consecutive } \\
\text { patients, median } \\
\text { follow-up } 56 \text { months }\end{array}$ & $\begin{array}{l}\text { Biotrol Iryflex } \\
\text { (Braun Medical BV, } \\
\text { Oss, The } \\
\text { Netherlands) }\end{array}$ & $\begin{array}{l}\text { - Reported to be effective and beneficial } \\
\text { in } 54 \% \text { of patients } \\
\text { - Overall, } 45 \% \text { long-term success rate } \\
\text { - Effective in } 47 \% \text { of patients with } \\
\text { soiling, } 41 \% \text { with faecal incontinence, } \\
65 \% \text { with obstructive defaecation } \\
\text { disturbances and } 79 \% \text { after low anterior } \\
\text { resection or pouch surgery } \\
\text { - Irrigation-related problems in } 74 \% \\
\text { of regular users }\end{array}$ & $\begin{array}{l}\text { + Large number of } \\
\text { patients } \\
+ \text { Structured } \\
\text { questionnaire } \\
\text { - End points not } \\
\text { defined } \\
\text { - Non-comparative }\end{array}$ & $\begin{array}{l}\text { Gosselink } \\
\text { et } a l^{34}\end{array}$ \\
\hline $\begin{array}{l}\text { Anterior } \\
\text { resection, } \\
n=30\end{array}$ & $\begin{array}{l}\text { Interview by phone } \\
\text { follow-up study and } \\
\text { chart review }\end{array}$ & $\begin{array}{l}\text { Biotrol Irrimatic } \\
\text { pump (Braun } \\
\text { Medical BV) }\end{array}$ & $\begin{array}{l}\text { - In all, } 12 \text { of } 21 \text { patients who still } \\
\text { performed irrigation were (pseudo) continent } \\
\text { - Reduction in symptoms of incontinence } \\
\text { (William's score) }\end{array}$ & - Non-comparative & $\begin{array}{l}\text { Koch } \\
\text { et al. }\end{array}$ \\
\hline $\begin{array}{l}\text { Anterior } \\
\text { resection, } \\
n=10\end{array}$ & Descriptive & $\begin{array}{l}\text { Commercially } \\
\text { available } \\
\text { colostomy washout } \\
\text { set with cone tip } \\
\text { (Hollister or Tokyo } \\
\text { Eizia) }\end{array}$ & $\begin{array}{l}\text { Resolved frequent urge to defaecate } \\
\text { in all patients }\end{array}$ & $\begin{array}{l}\text { - Non-comparative } \\
\text { - End points not } \\
\text { defined } \\
\text { - Small number of } \\
\text { patients }\end{array}$ & $\begin{array}{l}\text { Iwama } \\
\text { et al. }\end{array}$ \\
\hline
\end{tabular}


Table 1 Continued

\begin{tabular}{|c|c|c|c|c|c|}
\hline Patients & Study design & System/equipment & Main findings & $\begin{array}{l}\text { Strengths }(+) / \\
\text { limitations (-) }\end{array}$ & Reference \\
\hline $\begin{array}{l}\text { Post-dynamic } \\
\text { graciloplasty, } \\
n=46\end{array}$ & $\begin{array}{l}\text { Questionnaire } \\
\text { follow-up study }\end{array}$ & $\begin{array}{l}\text { Biotrol Irrimatic } \\
\text { pump or } \\
\text { irrigation bag }\end{array}$ & $\begin{array}{l}\text { - (Pseudo) continence achieved in } \\
37 \% \text { of patients } \\
\text { - Constipation resolved in } 30 \% \text { of patients } \\
\text { - Satisfaction with irrigation in } 81 \% \\
\text { of patients } \\
\text { - Side effects reported in } 61 \% \text { of patients }\end{array}$ & - Non-comparative & $\begin{array}{l}\text { Koch } \\
\text { et al. }\end{array}$ \\
\hline $\begin{array}{l}\text { Mixed } \\
\text { continence } \\
\text { disturbances, } \\
n=32\end{array}$ & $\begin{array}{l}\text { Questionnaire follow-up } \\
\text { and review of hospital } \\
\text { records, median } \\
\text { follow-up } 18 \text { months }\end{array}$ & $\begin{array}{l}\text { Conventional } \\
\text { colostomy } \\
\text { irrigation set }\end{array}$ & $\begin{array}{l}\text { - Success reported in } 79 \% \text { of patients with } \\
\text { faecal soiling and } 38 \% \text { with faecal incontinence } \\
\text { - Irrigation beneficial in } 92 \% \text { of patients with } \\
\text { faecal soiling who did not discontinue irrigation }\end{array}$ & $\begin{array}{l}\text { - Non-comparative } \\
\text { - End points not } \\
\text { defined }\end{array}$ & $\begin{array}{l}\text { Briel } \\
\text { et al. }\end{array}$ \\
\hline $\begin{array}{l}\text { Mixed, } n=37 \\
\text { (including } \\
\text { spinal cord } \\
\text { lesion, spina } \\
\text { bifida, } \\
\text { complicated anal } \\
\text { sphincter lesions } \\
\text { or anorectal } \\
\text { surgery and } \\
\text { irradiation } \\
\text { therapy) }\end{array}$ & $\begin{array}{l}\text { Questionnaire follow-up } \\
\text { and review of hospital } \\
\text { records } \\
\end{array}$ & $\begin{array}{l}\text { Enema } \\
\text { Continence } \\
\text { Catheter }\end{array}$ & $\begin{array}{l}\text { - Reduced symptoms in } 3 \text { of } 16 \text { adults } \\
\text { with constipation/obstructed defaecation } \\
\text { - Reduced frequency of fecal incontinence } \\
\text { in } 4 \text { of } 9 \text { adults } \\
\text { - Reduced symptoms in } 10 \text { of } 11 \text { children } \\
\text { with colorectal dysfunction, mainly due } \\
\text { to spina bifida }\end{array}$ & $\begin{array}{l}\text { - End points not } \\
\text { defined } \\
\text { - Non comparative } \\
\text { - Small number of } \\
\text { patients }\end{array}$ & $\begin{array}{l}\text { Krogh } \\
\text { et al. }\end{array}$ \\
\hline $\begin{array}{l}\text { Mixed, } n=40 \\
\text { (spina bifida, } \\
n=6, \mathrm{MS} \\
n=3, \text { spinal } \\
\text { injury, } n=3 \text { ) }\end{array}$ & $\begin{array}{l}\text { Questionnaire follow-up } \\
\text { study and retrospective } \\
\text { database search, mean } \\
\text { follow-up } 6.8 \text { years for } \\
\text { children and } 8.5 \text { years } \\
\text { for adults }\end{array}$ & $\begin{array}{l}\text { Mainly Iryflex } \\
\text { (Braun Medical } \\
\text { BV); occasionally } \\
\text { hand RCI (Braun } \\
\text { Medical BV) }\end{array}$ & $\begin{array}{l}\text { - Overall, } 63 \% \text { of patients still using irrigation } \\
\text { at mean follow-up of } 8.5 \text { years } \\
\text { - Overall, } 88 \% \text { of patients satisfied } \\
\text { with irrigation } \\
\text { - Higher satisfaction among younger adults } \\
\text { (aged }<40 \text { years versus }>40 \text { years) and } \\
\text { among children versus adults }\end{array}$ & $\begin{array}{l}\text { - End points not } \\
\text { defined } \\
\text { - Non-comparative }\end{array}$ & $\begin{array}{l}\text { Cazemier } \\
\text { et } \text { al. }^{22}\end{array}$ \\
\hline $\begin{array}{l}\text { Mixed, } n=39 \\
(\mathrm{MS}, n=1)\end{array}$ & $\begin{array}{l}\text { Prospective } \\
\text { study - assessment at } \\
\text { baseline, and } 3,6 \text { and } \\
12 \text { months }\end{array}$ & $\begin{array}{l}\text { Biotrol Irrimatic } \\
\text { pump or irrigation } \\
\text { bag }\end{array}$ & $\begin{array}{l}\text { - Reduced symptoms of incontinence } \\
\text { (Parks' incontinence score) at } 3 \text { months, } \\
6 \text { months and } 1 \text { year } \\
\text { - Major improvement in symptom in } \\
3 \text { of } 10 \text { patients with constipation } \\
\text { - Decreased mean score for feeling } \\
\text { of incomplete evacuation at } 3 \text { months, } \\
6 \text { months and } 1 \text { year } \\
\text { - Improved QoL (Short Form } 36 \text { health } \\
\text { survey and American Society of Colon and } \\
\text { Rectal Surgery quality of life questionnaire) }\end{array}$ & $\begin{array}{l}\text { + Prospective } \\
\text { + Defined end points } \\
\text { - Non-comparative } \\
\text { - Small number of } \\
\text { patients }\end{array}$ & $\begin{array}{l}\text { Koch } \\
\text { et } \text { ll. }^{32}\end{array}$ \\
\hline
\end{tabular}

Abbreviations: MS, multiple sclerosis; NBD, neurogenic bowel dysfunction; QoL, quality of life; RCT, randomized controlled trial; SCl, spinal cord injury; TAl, transanal irrigation; UTI, urinary tract infection.

${ }^{a}$ No new data were collected for these patients in the TAl arm of the RCT.

primarily traumatic. The injury was at the high supraconal level (T9 or above) for the majority of patients, and patients with both complete and incomplete injury were included. The predominant symptom was constipation. At the time of termination of the treatment, significantly reduced severity of constipation and faecal incontinence symptoms were reported in the groups using TAI (intention-to-treat analysis). Significant results in favour of TAI were found for all outcome measures, both symptom burden and quality-of-life scores. Additional benefits of the TAI approach were greater general satisfaction $(P=0.023)$, reduced time spent on bowel management (47.0 min versus 74.4 min per day; $P=0.04$ ) and fewer urinary tract infections $(P=0.0052)$. This robust clinical trial was the first to show an effective and welltolerated prospective intervention in NBD.

At the end of this RCT, 20 of the 45 patients originally randomized to conservative bowel management were switched to TAI, and a total of 62 adults were followed up for 10 weeks. $^{18}$ The outcome of this extension study confirmed the clinical outcomes of the initial report (Table 1). An attempt to define predictors of which patients may succeed using TAI did not identify any factors (such as demographic, symptomatic or injury related) using a general linear model. ${ }^{18}$

A subsequent prospective, non-randomized study of 33 patients with NBD of varying aetiology further confirmed 
the improvement in symptoms and quality of life with TAI, using Peristeen, and tap water. ${ }^{19}$ Success rates were similar for faecal incontinence (68\%) and constipation (63\%), and a reduction in pharmaceutical use, time spent on evacuation and dependence on caregivers was observed.

Follow-up studies have described the successful long-term use of TAI in the SCI population. Two similar studies, ${ }^{20,21}$ each with follow-up of nearly 10 years, assessed treatment success (defined as the patient still using TAI at follow-up, or whose symptoms had resolved while using it, or who had died from unrelated causes while using it). The irrigation systems used included rectal balloon catheters and systems with a cone-shaped colostomy tip. ${ }^{20,21}$ Both studies included adults and children with bowel dysfunction of various aetiologies. For 74 patients with traumatic SCI, the success rates were $50 \%$ for complete injuries, $58 \%$ for high incomplete injuries and $53 \%$ for low incomplete injuries. ${ }^{20}$ The second long-term follow-up study reported success for $62 \%$ of the 68 patients with SCI. ${ }^{21}$ These authors speculated that per-protocol success rates could be enhanced by undertaking a 3-month trial period of irrigation.

Taken together, these data show that for patients with SCI, TAI is more effective than conservative bowel management, ${ }^{17}$ resulting in an improvement in symptoms ${ }^{18,19}$ and quality of life, ${ }^{19}$ and that success is maintained in the long term. ${ }^{16,20,21}$

\section{Efficacy of TAI in patients with spina bifida}

Data on the efficacy of TAI in patients with spina bifida consist mainly of observational studies in children (or youths) with faecal incontinence (Table 1). Patients with spina bifida have also been included in TAI studies conducted in mixed patient populations, but their data have not been separately reported. ${ }^{17,18,22}$

A prospective review of 40 patients with spina bifida (mean age 12.5 years; range 6-25 years) using TAI with Peristeen, because they did not respond satisfactorily to conventional bowel management for NBD, was conducted. The mean follow-up was 12 months. In all 35 children who completed the study, the use of TAI was associated with significant improvements in symptoms of bowel dysfunction (such as difficulty and/or pain during defaecation, feeling of incomplete emptying, abdominal pain or discomfort before or after defaecation, as well as sweats or headache during or after defaecation). Patients' independence was also improved: with conservative bowel management, $28 \%$ of the patients were partially or totally independent in terms of evacuating their bowel, whereas with TAI, 46\% were partially or totally independent. Patients' opinion of their intestinal functionality was also significantly improved $(P<0.0001)$, and no adverse events were reported. ${ }^{23}$

The earliest identified study investigated the Enema Continence Catheter and lukewarm saline in 112 patients (aged 4-20 years) with spina bifida and faecal incontinence. Continence (fewer than three minor leakages per month) was achieved in all cases. ${ }^{24}$ Subsequently, this catheter underwent modification and, in a further open study, was used to successfully treat 7 of 10 children with spina bifida and faecal incontinence over a follow-up period of 4-30 months. ${ }^{25}$ A subsequent report on the Shandling catheter described the achievement of continence in 32 of 33 patients (aged 5-22 years with spina bifida and faecal incontinence), which was maintained during follow-up of 24-35 months, with the exception of a single child who had undergone three surgical procedures for rectal prolapse. ${ }^{26}$

A 30-month follow-up study evaluated TAI with saline using the Enema Continence Catheter in 30 children with spina bifida and in 1 child with SCI. ${ }^{27}$ During the study, the proportion of children with continent stools increased from 28 to $94 \%(P<0.01)$ and the proportion of constipated stools decreased from 55 to $15 \%(P<0.01){ }^{27}$

Cone-based TAI systems have also been used in children with spina bifida. A retrograde tap water enema (with lukewarm tap water run from a plastic bag into the bowel through an irrigation cone) achieved continence in 21 of 24 children with spina bifida and faecal incontinence. ${ }^{28}$ Similarly, hand-warm tap water was used with a cone-tipped catheter in 41 children with spina bifida (aged 7 months to 22 years) who experienced faecal incontinence (27\%), constipation (27\%) or both. ${ }^{29}$ After a mean follow-up of 33 months, complete faecal continence was achieved in $66 \%$ of the patients, with constipation occurring only occasionally. Overall, $63 \%$ of the parents/children rated satisfaction with the procedure as high and $37 \%$ as good. ${ }^{29}$

Mattsson and Gladh $^{30}$ undertook a study of TAI with a Stoma Cone Irrigation Set (Colotip, Coloplast A/S, Humlebaek, Denmark), which worked satisfactorily for 35 of 40 children with spina bifida with a median follow-up of 18 months. Relief of constipation was successfully achieved in all 40 children and faecal continence was achieved in 35; the other 5 children had faecal soiling less than once per month. ${ }^{30}$ Overall, $90 \%$ of parents spontaneously reported general improvements in the well-being of the child, including improved appetite, increased alertness and fewer complaints of stomach pain and headache. ${ }^{30}$

There are few data from clinical studies of TAI in adults with spina bifida. Of the 15 adults with spina bifida included in one observational study, 6 were prescribed retrograde colonic washout (system type not reported) as all or part of their bowel management routine: 3 of 6 patients achieved continence. $^{31}$ A prospective, non-randomized study included 12 adults with spina bifida in a mixed population of 33 patients with NBD and reported significant improvement in quality of life compared with baseline after 3 weeks of TAI with Peristeen. ${ }^{19}$

Two long-term (10-year) follow-up studies in adults and children $^{20,21}$ reported success rates of $50 \%(n=32)$ using a rectal balloon catheter, cone-shaped colostomy tip or other system $^{20}$ and of $67 \%(n=18)$ using TAI with Peristeen or a cone-shaped colostomy tip. ${ }^{21}$

Although less robust than data in patients with SCI, taken together, these data show that TAI can reduce constipation ${ }^{27}$ and achieve faecal continence in both children ${ }^{23-26,28-30}$ and adults $^{31}$ with spina bifida, achieving an improvement in symptoms, ${ }^{27}$ independence ${ }^{23}$ and quality of life, ${ }^{30}$ and remaining effective in the long term. ${ }^{16,20,21}$ 


\section{Efficacy of TAl in patients with multiple sclerosis and other causes of NBD}

At present, the majority of data on the efficacy of TAI in patients with multiple sclerosis comes from observational studies (Table 1). Patients with multiple sclerosis have also been included in other studies with mixed patient populations, but their outcomes have not been reported separately. ${ }^{19,22,32}$

The 10-year follow-up studies in adults and children ${ }^{20,21}$ included some patients with multiple sclerosis. Overall, reported success rates were $40 \%$ for patients $(n=25)$ using a rectal balloon catheter, cone-shaped colostomy tip or other systems, ${ }^{20}$ and $50 \%$ for patients $(n=10)$ using either Peristeen or a cone-shaped colostomy tip. ${ }^{21}$ Results obtained from a small study in 10 patients with NBD, including 3 with multiple sclerosis, suggest that TAI may be particularly beneficial in those with reduced rectal compliance. ${ }^{33}$

Success with TAI has been achieved in patients with Parkinson's disease ( 2 of 4 patients) ${ }^{20,21}$ and stroke, cerebral thrombosis or cerebral palsy (11 of 22 patients). ${ }^{16,20,21,25}$ Taken together, these data suggest that TAI is an effective therapy for bowel dysfunction secondary to a range of neurological disorders, including multiple sclerosis, but more work needs to be done to expand the evidence base in these populations.

\section{Efficacy of TAl in other populations}

There are reported instances of successful implementation of TAI for a wide variety of other causes of bowel dysfunction. In a study by Christensen et al., ${ }^{21}$ success with TAI was reported in patients with idiopathic faecal incontinence (51\%, $n=49)$, idiopathic constipation (34\%, $n=79)$, disrupted sphincter $(52 \%, n=21)$, sequelae of rectal $(40 \%$, $n=15)$ or anal surgery $(25 \%, n=12)$ and incontinence secondary to rectal prolapse $(24 \%, n=21)$. Factors reported to correlate with a positive outcome with TAI include NBD and anal insufficiency as the underlying pathology, low rectal volume at urge to defaecate, low maximal rectal capacity and low anal squeeze pressure increment. ${ }^{21}$ In a study of patients with defaecation disturbances of mixed aetiology, including soiling (cause not defined, $n=32$ ), incontinence (cause not defined, $n=71$ ), obstructed defaecation $(n=37)$ and post low anterior resection or pouch surgery $(n=29)$, TAI was considered effective by $54 \%$ of patients. TAI was found to be particularly effective among patients with obstructive defaecation or defaecation disturbances after low anterior resection or pouch surgery, with the procedure reported to be effective in 65 and $79 \%$ of patients, respectively. ${ }^{34}$ Importantly, in the post-operative population with an anastomosis just above the anus, there were no major complications with TAI after a mean follow-up of 56 months. Other reports have documented the use of TAI after anterior resection ${ }^{35,36}$ or after dynamic graciloplasty, ${ }^{37}$ and various studies have enrolled mixed patient populations, including patients with a history of abdominal surgery, idiopathic (neurogenic) bowel dysfunction, irritable bowel syndrome, anorectal malformation, coloanal anastomosis, diabetes mellitus, multiple sclerosis, SCI and neural tube closure defect. ${ }^{29,32,34,38,39}$ Owing to the heterogeneous nature of these mixed patient populations and the low number of patients of each type, further investigation is required to confirm the efficacy of TAI in each of these settings. The potential of TAI in the treatment of the very distressing low anterior resection syndrome is of particular interest and merits further investigation, although this will need a cautious approach to avoid the possibility of perforation in this at-risk group.

\section{Safety of TAI}

Symptoms before, during and after defaecation are common in patients with NBD. In the RCT, symptoms reported during or immediately after defaecation when using TAI included abdominal pain (15.7\% of patients), sweating (10.5\%), chills (7.0\%), pronounced general discomfort (5.9\%), dizziness $(5.4 \%)$, nausea $(3.0 \%)$, headache $(3.0 \%)$, facial flushing $(2.7 \%)$ and anorectal pain (1.4\%). ${ }^{17}$ These symptoms do not seem to be related to TAI per se, being equally prevalent in patients using conservative bowel management, with the exception of sweating, which was significantly less common in the TAI arm. ${ }^{17}$ Long-term follow-up studies ${ }^{16,20,21}$ suggest that such symptoms are well tolerated by long-term users of TAI.

There is a report of a child who experienced autonomic dysreflexia when using the Enema Continence Catheter. ${ }^{27}$ However, no cases of autonomic dysreflexia were reported in the TAI arm of the $\mathrm{RCT}^{17}$; in fact, the associated symptoms - sweating, headache, flushing, pronounced general discomfort - tended to be more common in the conservative bowel management group $(17.3 \%$ of patients in the TAI group versus $30 \%$ in the conservative management group; $P=0.099)$.

True adverse effects with TAI are infrequent. In the RCT, four patients with SCI experienced non-serious or unrelated adverse effects with TAI, ${ }^{17}$ and in the extension study, there was one event. ${ }^{18}$ Other studies have shown no adverse events during TAI with Peristeen for 3 weeks and 1 year ${ }^{19,23}$ or TAI with the Enema Continence Catheter for 30 months. ${ }^{27}$ There have been single reports of rectal prolapse and pain. ${ }^{30}$

Bowel perforation, a serious and potentially fatal complication, has been reported; ${ }^{40-43}$ however, the circumstances - such as the type of system used, the type of user and the level of training received by the user-are not clear in all cases. Long-term follow-up studies calculated that non-fatal bowel perforation occurred in $\sim 1$ per 50000 irrigations. $^{20,21}$ It warrants consideration that because the risk of bowel perforation accumulates with the number of irrigations performed, the risk of bowel perforation for an individual using TAI over the duration of a lifetime may be higher than the risk observed in shorter-duration clinical trials. Before starting TAI, patients should be counselled that it is an invasive procedure with the potential to cause harm and, in rare cases, even death. However, the risks of TAI should be viewed in context of both the potential improvement in 
quality of life and the risk associated with alternative options when conservative management fails. More invasive treatments for NBD, such as elective colonic surgery and creation of a stoma, are associated with far greater morbidity and mortality than TAI. ${ }^{44}$ Other reported unwanted effects, including rectal burn, stricture and inflammation (chemical colitis), have been associated with non-recommended extensions of the irrigation technique, such as using hot water or enema additives. In addition, comorbidity such as hyponatraemia ${ }^{45,46}$ and gut lesions ${ }^{47}$ increase the likelihood of perforation that is not attributed specifically to TAI. Theoretically, there is a risk that TAI disturbs the gastrointestinal microflora and causes iatrogenic infection; ${ }^{48}$ however, the current available data do not indicate that this occurs. TAI has no demonstrable effect on urodynamics. ${ }^{49}$

In a prospective, long-term follow-up (median, 5.7 years; range 3.1-9.4 years) of anal physiology in patients with chronic idiopathic constipation $(n=12)$ or idiopathic faecal incontinence $(n=10)$ treated with TAI, no decrease in anal sphincter function was observed among patients with constipation. Although a decrease in anal sphincter function was observed among patients with incontinence, this was considered related to the natural history of idiopathic faecal incontinence rather than to side effects from long-term TAI use. TAI was also found to increase rectal tolerability but had no effect on rectal compliance; the former was hypothesized to be explained by patients getting used to irrigation rather than to changes in mechanical rectal wall properties. ${ }^{50}$

In the RCT, approximately one-quarter of patients in the TAI group did not complete the study. ${ }^{17}$ Early failures were mainly attributed to practical problems; of the 12 withdrawals, 2 were before training, 3 were because of repeated expulsion of the catheter and 1 each because of rectal balloon bursts, lack of compliance, dislike of treatment, lack of effect and adverse effects (pain due to faecal impaction). ${ }^{17}$ Two patients were lost to follow-up. Similarly, the greatest proportion of discontinuations occurred in the early stages of the long-term follow-up study of Faaborg et al. ${ }^{20}$ Nearly one in five patients discontinued during the first few months but, subsequently, the dropout became more gradual, yielding a success rate of $35 \%$ in 3 years, which stabilized for long-term use.

All potential new users of TAI should undergo a pretreatment evaluation to exclude potential contraindications to treatment. To both optimize the likelihood of a successful treatment outcome and minimize risk of adverse effects, patients should also receive thorough instruction and supervision from an experienced health-care professional before attempting to perform TAI alone.

New users of TAI should expect a period in which to adapt and optimize the irrigation regimen to their individual needs. ${ }^{17}$ Parameters that may be individualized include the volume of water used, the frequency and timing of irrigation and, in the case of Peristeen (which has an inflatable balloon to hold the catheter in place during irrigation), the amount of air pumped into the balloon. It is important that both new users of anal irrigation and their caregivers accept that the procedure may not be optimal straight away and that an adaptation period, typically 4-6 weeks, ${ }^{17}$ is usually required. This adaptation phase may go some way to explain the relatively high initial dropout rate observed in some studies. It follows that expectations should be carefully managed in new users of TAI, to encourage compliance and provide the opportunity for the procedure to be optimized in line with characteristics and requirements of the new user.

\section{TAI systems}

A direct comparison of the performance of the various TAI systems has not been conducted. The only head-to-head comparison is the RCT, which showed Peristeen to be significantly better than conservative bowel management across the range of parameters investigated. ${ }^{17}$ These are the most robust data currently available, with other observational data providing supportive evidence (Table 1).

A health economics assessment of the RCT found a lower total cost to society of self-administered TAI with Peristeen compared with conservative bowel management for patients with SCI. ${ }^{51}$ Although product-related costs were higher with TAI, this was offset by lower costs for a caregiver to help with bowel management and changes/washing due to leakage, as well lower costs associated with urinary tract infections, and less time spent by the patient on bowel management. ${ }^{51}$

\section{Discussion}

The benefits of TAI have been shown for patients with SCI in terms of significantly improved efficacy compared with conservative bowel management, ${ }^{17}$ reduction in symptoms of NBD, and improvement in quality of life. ${ }^{18,19}$ Data supporting the utility of TAI in patients with spina bifida are also accumulating, especially in terms of achieving faecal continence in children. ${ }^{24-26,28-30}$

Fewer data have been published for other patient populations, but further investigation of TAI in clinical trials is clearly justified. Observational data indicate that patients with multiple sclerosis benefit from $\mathrm{TAI}^{20,21}$ and studies are required specifically in this patient population. The evidence in other groups-including patients with idiopathic faecal incontinence and idiopathic constipation, stroke and cerebral palsy, Parkinson's disease, and defaecation disturbances after low anterior resection or pouch surgery ${ }^{16,20,21,34}$ _ similarly requires expanding.

It is evident that TAI with specialized rectal catheters is superior to conservative management. The research agenda, nevertheless, needs to be developed. Identifying predictive factors (possibly anorectal physiological factors or bowel transit-related factors) would help tailor treatment towards optimizing benefit in individual patients, as well as help identify particularly responsive patient groups. Prospectively collected long-term (10 years plus) data on safety and efficacy are essential. A prospective trial of escalating stepwise treatment versus conservative management for NBD, in terms of quality-of-life outcomes and safety, would provide this sort of long-term data, and establish 
the place of TAI in the management of NBD. However, such studies are particularly difficult to undertake. The problems of defining completeness of injury, and variations in policies between care units, mean that study populations are likely to be extremely heterogeneous. Furthermore, the absence of a reproducible and valid subjective scoring instrument limits the interpretability of studies in this area, in which symptom improvement-not cure-is the aim. Nevertheless, the chronicity and severity of bowel symptoms in patients with nerve disorders warrants these exhaustive studies, aiming for better patient classification and use of commonly accepted symptom scores.

Apart from one single centre study, ${ }^{15}$ most publications have looked at subjective symptomatic outcome data. The results of this study have provided some validation for the subsequent use of symptom scores. It is important to revalidate this relationship between standard accepted symptom scores and emerging manometric measures.

In patients with SCI, significant benefits of TAI with the Peristeen system have been demonstrated in a head-to-head comparison with conservative management in terms of efficacy, quality of life and health economics. The evidence base for other irrigation systems and of TAI in other patient populations is largely observational in nature with a predominance of descriptive studies (Table 1 ). It would be advantageous to further investigate TAI in prospective studies, with defined patient populations and stratification by baseline characteristics. There is currently a need for prospective RCTs of TAI in adult patients with spina bifida and multiple sclerosis.

\section{Conflict of interest}

Dr Emmanuel has received travel support and honoraria for participation in advisory boards for Coloplast $A / S$, Humlebaek, Denmark.

\section{Acknowledgements}

Dr Emmanuel is grateful for the motivation and support to prepare the paper from Dagnia Looms (an employee of Coloplast A/S, Humlebaek, Denmark) and acknowledges writing assistance from Elements Communications, Westerham, UK, funded by Coloplast.

\section{References}

1 Liu CW, Huang CC, Yang YH, Chen SC, Weng MC, Huang MH. Relationship between neurogenic bowel dysfunction and healthrelated quality of life in persons with spinal cord injury. J Rehabil Med 2009; 41: 35-40.

2 Menter R, Weitzenkamp D, Cooper D, Bingley J, Charlifue S, Whiteneck G. Bowel management outcomes in individuals with long-term spinal cord injuries. Spinal Cord 1997; 35: 608-612.

3 Naicker AS, Roohi SA, Naicker MS, Zaleha O. Bowel dysfunction in spinal cord injury. Med J Malaysia 2008; 63: 104-108.

4 Hinds JP, Eidelman BH, Wald A. Prevalence of bowel dysfunction in multiple sclerosis. A population survey. Gastroenterology 1990; 98: 1538-1542.
5 Krogh K, Ostergaard K, Sabroe S, Laurberg S. Clinical aspects of bowel symptoms in Parkinson's disease. Acta Neurol Scand 2008; 117: 60-64.

6 Verhoef M, Lurvink M, Barf HA, Post MW, van Asbeck FW, Gooskens RH et al. High prevalence of incontinence among young adults with spina bifida: description, prediction and problem perception. Spinal Cord 2005; 43: 331-340.

7 Yuan Z, Cheng W, Hou A, Wang W, Zhang S, Liu D et al. Constipation is associated with spina bifida occulta in children. Clin Gastroenterol Hepatol 2008; 6: 1348-1353.

8 Lynch AC, Anthony A, Dobbs DR, Frizelle FA. Anorectal physiology following spinal cord injury. Spinal Cord 2000; 38: 573-580.

9 Krogh K, Mosdal C, Laurberg S. Gastrointestinal and segmental colonic transit times in patients with acute and chronic spinal cord lesions. Spinal Cord 2000; 38: 615-621.

10 Krogh K, Olsen N, Christensen P, Madsen JL, Laurberg S. Colorectal transport during defecation in patients with lesions of the sacral spinal cord. Neurogastroenterol Motil 2003; 15: 25-31.

11 Vallès M, Vidal J, Clavé P, Mearin F. Bowel dysfunction in patients with motor complete spinal cord injury: clinical, neurological, and pathophysiological associations. Am J Gastroenterol 2006; 101: 2290-2299.

12 Roach MJ, Frost FS, Creasey G. Social and personal consequences of acquired bowel dysfunction for persons with spinal cord injury. J Spinal Cord Med 2000; 23: 263-269.

13 Coggrave M, Norton C, Wilson-Barnett J. Management of neurogenic bowel dysfunction in the community after spinal cord injury: a postal survey in the United Kingdom. Spinal Cord 2009; 47: 323-330.

14 Haas U, Geng V, Evers GC, Knecht H. Bowel management in patients with spinal cord injury-a multicentre study of the German speaking society of paraplegia (DMGP). Spinal Cord 2005; 43: 724-730.

15 Christensen $\mathrm{P}$, Olsen N, Krogh K, Bacher T, Laurberg S. Scintigraphic assessment of retrograde colonic washout in fecal incontinence and constipation. Dis Colon Rectum 2003; 46: 68-76.

16 Christensen P, Kvitzau B, Krogh K, Buntzen S, Laurberg S. Neurogenic colorectal dysfunction-use of new antegrade and retrograde colonic wash-out methods. Spinal Cord 2000; 38: 255-261.

17 Christensen P, Bazzocchi G, Coggrave M, Abel R, Hultling C, Krogh $\mathrm{K}$ et al. A randomized, controlled trial of TAI versus conservative bowel management in spinal cord-injured patients. Gastroenterology 2006; 131: 738-747.

18 Christensen P, Bazzocchi G, Coggrave M, Abel R, Hulting C, Krogh $\mathrm{K}$ et al. Outcome of TAI for bowel dysfunction in patients with spinal cord injury. J Spinal Cord Med 2008; 31: 560-567.

19 Del Popolo G, Mosiello G, Pilati C, Lamartina M, Battaglino F, Buffa P et al. Treatment of neurogenic bowel dysfunction using TAI: a multicenter Italian study. Spinal Cord 2008; 46: 517-522.

20 Faaborg PM, Christensen P, Kvitsau B, Buntzen S, Laurberg S, Krogh K. Long-term outcome and safety of transanal colonic irrigation for neurogenic bowel dysfunction. Spinal Cord 2009; 47: 545-549.

21 Christensen P, Krogh K, Buntzen S, Payandeh F, Laurberg S. Longterm outcome and safety of TAI for constipation and fecal incontinence. Dis Colon Rectum 2009; 52: 286-292.

22 Cazemier M, Felt-Bersma RJ, Mulder CJ. Anal plugs and retrograde colonic irrigation are helpful in fecal incontinence or constipation. World J Gastroenterol 2007; 13: 3101-3105.

23 López Pereira P, Salvador OP, Arcas JA, Martínez Urrutia MA, Romera RL, Monereo EJ. TAI for the treatment of neuropathic bowel dysfunction. I Pediatr Urol 2009 (e-pub ahead of print 5 August 2009).

24 Shandling B, Gilmour RF. The Enema Continence Catheter in spina bifida: successful bowel management. J Pediatr Surg 1987; 22: 271-273.

25 Walker J, Webster P. Successful management of faecal incontinence using the Enema Continence Catheter. Z Kinderchir 1989; 44(Suppl 1): 44-45. 
26 Eire PF, Cives RV, Gago MC. Faecal incontinence in children with spina bifida: the best conservative treatment. Spinal Cord 1998; 36: 774-776.

27 Liptak GS, Revell GM. Management of bowel dysfunction in children with spinal cord disease or injury by means of the Enema Continence Catheter. J Pediatr 1992; 120: 190-194.

28 Vande Velde S, Van Biervliet S, Van Renterghem K, Van Laecke E, Hoebeke P, Van Winckel M. Achieving fecal continence in patients with spina bifida: a descriptive cohort study. J Urol 2007; 178: 2640-2644.

29 Schöller-Gyüre M, Nesselaar C, van Wieringen H, van Gool JD. Treatment of defecation disorders by colonic enemas in children with spina bifida. Eur J Pediatr Surg 1996; 6(Suppl 1): 32-34.

30 Mattsson S, Gladh G. Tap-water enema for children with myelomeningocele and neurogenic bowel dysfunction. Acta Paediatr 2006; 95: 369-374.

31 Wright L. The efficacy of bowel management in the adult with spina bifida. Eur J Pediatr Surg 2002; 12(Suppl 1): S41-S43.

32 Koch SM, Melenhorst J, van Gemert WG, Baeten CG. Prospective study of colonic irrigation for the treatment of defaecation disorders. Br J Surg 2008; 95: 1273-1279.

33 Storrie JB, Harding S, Raeburn AJ, Trivedi PM, Preziosi G, Emmanuel AV. Medium-term outcome with trans-anal irrigation for neurogenic bowel dysfunction is related to rectal compliance. Gastroenterology 2009; 136(Suppl 1): A-218.

34 Gosselink MP, Darby M, Zimmerman DD, Smits AA, van Kessel I, Hop WC et al. Long-term follow-up of retrograde colonic irrigation for defaecation disturbances. Colorectal Dis 2004; 7: 65-69.

35 Koch SM, Rietveld MP, Govaert B, van Gemert WG, Baeten CG. Retrograde colonic irrigation for faecal incontinence after low anterior resection. Int J Colorectal Dis 2009; 24: 1019-1022.

36 Iwama T, Imajo M, Yaegashi K, Mishima Y. Self washout method for defecational complaints following low anterior rectal resection. Jpn J Surg 1989; 19: 251-253.

37 Koch SM, Uludaa O, El Naggar K, van Gemert WG, Baeten CG. Colonic irrigation for defecation disorders after dynamic graciloplasty. Int J Colorectal Dis 2008; 23: 195-200.
38 Briel JW, Schouten WR, Vlot EA, Smits S, van Kessel I. Clinical value of colonic irrigation in patients with continence disturbances. Dis Colon Rectum 1997; 40: 802-805.

39 Krogh K, Kvitzau B, Jørgensen TM, Laurberg S. [Treatment of anal incontinence and constipation with TAI]. Ugeskr Laeger 1999; 161: 253-256

40 Biering-Sørensen F, Bing J, Berggreen P, Olesen GM. Rectum perforation during TAI: a case story. Spinal Cord 2009; 47: 266-267.

41 Handley DV, Rieger NA, Rodda DJ. Rectal perforation from colonic irrigation administered by alternative practitioners. Med J Aust 2004; 181: 575-576.

42 Paran H, Butnaru G, Neufeld D, Magen A, Freund U. Enemainduced perforation of the rectum in chronically constipated patients. Dis Colon Rectum 1999; 42: 1609-1612.

43 Gayer G, Zissin R, Apter S, Oscadchy A, Hertz M. Perforations of the rectosigmoid colon induced by cleansing enema: CT findings in 14 patients. Abdom Imaging 2002; 27: 453-457.

44 Branagan G, Tromans A, Finnis D. Effect of stoma formation on bowel care and quality of life in patients with spinal cord injury. Spinal Cord 2003; 41: 680-683.

45 Chertow GM, Brady HR. Hyponatraemia from tap-water enema. Lancet 1994; 344: 748.

46 Norlela S, Izham C, Khalid BA. Colonic irrigation-induced hyponatremia. Malays J Pathol 2004; 26: 117-118.

47 Sternberg A, Iuchtman M, Auslander L, Sternberg E, Robinson S, Fireman Z. Acute proctitis after a hot-water enema. J Clin Gastroenterol 1995; 20: 80-82.

48 Sisco V, Brennan PC, Kuehner CC. Potential impact of colonic irrigation on the indigenous intestinal microflora. J Manipulative Physiol Ther 1988; 11: 10-16.

49 de Kort LM, Nesselaar CH, van Gool JD, de Jong TP. The influence of colonic enema irrigation on urodynamic findings in patients with neurogenic bladder dysfunction. Br J Urol 1997; 80: 731-733.

50 Faaborg PM, Christensen P, Buntzen S, Laurberg S, Krogh K. Anorectal function after long-term use of transanal colonic irrigation. Colorectal Dis 2010 (e-pub ahead of print 12 January 2010).

51 Christensen P, Andreasen J, Ehlers L. Cost-effectiveness of TAI versus conservative bowel management for spinal cord injury patients. Spinal Cord 2009; 47: 138-143. 